\title{
Status, occurrence, intensity and impact of Argulosis in different brood stock ponds
}

\begin{abstract}
Fish lice belonging to the genus Argulus, is a hazardous ectoparasite for the hatchery farmers. In order to understand the occurrence, intensity and impact of Argulosis on carp fishes, the present study was conducted in three Fish Seed Multiplication Farms (Hatcheries), such as Kashipur Farm, Gouranadi Farm and Ujirpur Farm at Barisal District, Bangladesh from November 2012 to April 2013. Highest infestation (79.17\%) and intensity (41.34 per fish) of Argulus sp. were found in Ujirpur Hatchery, followed by those in Gouranadi (37.41\% and 13.17 per fish) and Kashipur (17.11\% and 10.91 per fish). Species-wise highest infestation $(65.71 \%)$ and intensity ( 25.86 per fish) were found in Labeo rohita, followed by Cyprinus carpio $(60.00 \%$ and 12.00 per fish) and the lowest in Cirrhinus mrigala (38.61\% and 5.02 per fish). Sex-wise infestation and intensity of Argulus sp. were always higher in the female carps than male and in all ponds, $L$. rohita had the highest rate of infestation than those in $C$. carpio and C. mrigala, and the most infested carps always were the females. Similar to the sex, length-wise highest prevalence and intensity of Argulosis were occurred in the largest size groups of carps and among them, the highest infestation was in $L$. rohita, followed by C. carpio and the lowest was in C. mrigala. The heavily infected fish experienced physical injury and showed abnormal swimming, and blood oozing from the fish caused red skin lesions and then secondary infection took place by bacteria (Aeromonas, Pseudomonas) and other parasites and fungi. Argulosis delayed the fish production and near about 15-30\% production losses were occurred due to lower growth, survival and production of infected carps in captivity.
\end{abstract}

Keywords: fish lice, Argulus, occurrence, impact, infestation, brood stock, production
Volume 4 Issue 5 - 2019

\author{
M Zahangir Alom,' Mt Shamima Yasmin,' M \\ Aminur Rahman, ${ }^{2}$ Saleha Khan ${ }^{3}$ \\ 'Department of Fisheries, Matshya Bhaban, Dhaka-1000, \\ Bangladesh \\ ${ }^{2}$ Department of Fisheries and Marine Bioscience, Jashore \\ University of Science and Technology, Jashore-7408, Bangladesh \\ ${ }^{3}$ Department of Fisheries Management, Bangladesh Agricultural \\ University, Mymensingh-2202, Bangladesh
}

\section{Correspondence: Dr. Md.Aminur Rahman, Professor, Department of Fisheries and Marine Bioscience, Jashore University of Science and Technology, Jashore-7408, Bangladesh, Tel +88 042 I-6I097 (Ext. 353), +88 01734-142726, Email aminur1963@gmail.com, amin2019@just.edu.bd}

Received: October 07, 2019 | Published: October 22, 2019

\section{Introduction}

Argulus referred to as "fish lice", an obligatory ectoparasite, is infecting many fresh water fish species. ${ }^{1}$ Tissue damage and secondary infections are caused by this ectoparasite. Argulus sp. could kill a larval eel with a single sting by injecting cytotoxic toxin into the host. ${ }^{2}$ The parasites and diseases constitute one of the important factors in regulating the populations in natural environment and in fish abundance. ${ }^{3}$ Argulus sp. can survive less than $48 \mathrm{~h}$ without fish host and even shorter period in juveniles. ${ }^{1}$ As juveniles hatch from eggs laid on the substrate, they require a fish host at least once during their short life span. This ectoparasite feeds by piercing the skin of its host, injecting a toxin and drawing off blood. ${ }^{4}$

The freshwater louse (Argulus sp.), a branchiuran ectoparasite, causing the disease Argulosis, has become a major threat like growth loss, under weight, immature mating and causes mortality of fish to the carp ponds in different fish farms and hatcheries throughout Bangladesh. The mortality of carp due to Argulus infection was first observed in an experimental pond in Chandpur Fisheries Research Station, Bangladesh. ${ }^{5}$ Since then many reports of Argulosis from fish ponds was documented in the country. Argulus from freshwater wild fish was also reported by Ahmed and Sanaullah. ${ }^{6}$ The maximum prevalence and intensity of infestation by Argulus sp. in carp pond occurred in the month of July and the female fishes were more susceptible to infestation, and the highest occurrence on pelvic region was reported by Ahmed and Chowdhury. ${ }^{7}$ The larger proportion of the female Argulus was occurred on the fish host, whereas free-swimming males were more numerous. ${ }^{1,8}$ When the eggs of Argulus foliaceus and its related species attach to fish, it can be seen with the naked eye. Argulus is transparent and may take on the color of the host. The attached area is often red and irritated as the fish undergo hemorrhagic reaction to the affection. Cyprinids and Percids are the main hosts for A. foliaceus. Infected fish swam in an erratic way. ${ }^{9}$ Around $80.5 \%$ infestation of $A$. foliaceus was occurred on young coregonid fishes during July to August and also was found to be correlated with the water temperature. ${ }^{10}$

The secondary bacterial or fungal infection, resulting from the Argulus infestation can reduce the commercial value of the fish. ${ }^{11}$ After treating with some pesticides, Argulosis continues to persist; most commercial chemicals are costly to farmers and these are toxic to aquatic fauna, particularly the zooplanktons. ${ }^{12}$ Randomly use of pesticides to treat fish diseases like Argulosis over a period could develop the resistance of pesticides effect and even cause high mortalities of the host. ${ }^{13}$ The present investigation has therefore been undertaken to know the condition, occurrence, intensity, impact and clinical symptoms of Argulosis.

\section{Materials and methods}

Three sampling areas of Fish Seed Multiplication Farms, such as Kashipur Farm (Table 1), Gouranadi Farm (Table 2) and Ujirpur Farm (Table 3) are situated at Barisal District, Bangladesh. The study was conducted from November 2012 to April 2013. The culture system in the study ponds was semi-intensive having moderate stocking density, where water exchange system was not well-developed and manure and chemical fertilizer applications were somewhat regular. 
Table I Brief information on the study ponds of Kashipur Farm

\begin{tabular}{|c|c|c|c|c|c|c|c|}
\hline \multirow{2}{*}{$\begin{array}{l}\text { Pond } \\
\text { no. }\end{array}$} & \multirow{2}{*}{$\begin{array}{l}\text { Length } \\
\text { (m) }\end{array}$} & \multirow{2}{*}{$\begin{array}{l}\text { Width } \\
\text { (m) }\end{array}$} & \multirow{2}{*}{$\begin{array}{l}\text { Water } \\
\text { depth } \\
(\mathrm{m})\end{array}$} & \multirow{2}{*}{$\begin{array}{l}\text { Stocking } \\
\text { density } \\
\text { (kg/ha) }\end{array}$} & \multicolumn{2}{|l|}{ Pesticides } & \multirow{2}{*}{ Cultured species (All ponds) } \\
\hline & & & & & Name & Dose & \\
\hline I & 70.0 & 60.5 & $\mathrm{I} .5$ & 2500 & & & \\
\hline 2 & 63.0 & 61.0 & 1.5 & 3700 & $\begin{array}{l}\text { Sumithion } \\
\text { and } \\
\text { Immithion }\end{array}$ & $\begin{array}{l}0.095- \\
0.125\end{array}$ & $\begin{array}{l}\text { Catla catla, Labeo rohita, Cirrhinus } \\
\text { mrigala, Puntius goniontus, } \\
\text { Hypophthalmicthys molitrix and } \\
\text { Aristichthys nobilis }\end{array}$ \\
\hline
\end{tabular}

Table 2 Brief information on the study ponds of Gouranadi Farm

\begin{tabular}{|c|c|c|c|c|c|c|c|}
\hline \multirow{2}{*}{$\begin{array}{l}\text { Pond } \\
\text { no. }\end{array}$} & \multirow{2}{*}{$\begin{array}{l}\text { Length } \\
(\mathrm{m})\end{array}$} & \multirow{2}{*}{$\begin{array}{l}\text { Width } \\
\text { (m) }\end{array}$} & \multirow{2}{*}{$\begin{array}{l}\text { Water } \\
\text { depth } \\
\text { (m) }\end{array}$} & \multirow{2}{*}{$\begin{array}{l}\text { Stocking } \\
\text { density } \\
\text { (kg/ha) }\end{array}$} & \multicolumn{2}{|l|}{ Pesticides } & \multirow{2}{*}{$\begin{array}{l}\text { Cultured species } \\
\text { (All ponds) }\end{array}$} \\
\hline & & & & & Name & Dose & \\
\hline I & 50.5 & 40.4 & 0.75 & 3211 & \multirow{4}{*}{$\begin{array}{l}\text { Sumithion, } \\
\text { Immithion and } \\
\text { Marshal }\end{array}$} & \multirow{4}{*}{$0.085-0.125$} & \multirow{4}{*}{$\begin{array}{l}\text { Catla catla, Labeo } \\
\text { rohita and Cirrhinus } \\
\text { mrigala }\end{array}$} \\
\hline 2 & 70.0 & 60.0 & 0.8 & 4693 & & & \\
\hline 3 & 70.0 & 78.0 & 0.8 & 2964 & & & \\
\hline 4 & 67.5 & 60.0 & 0.7 & 1729 & & & \\
\hline
\end{tabular}

Table 3 Brief information on the study pond of Ujirpur Farm

\begin{tabular}{|c|c|c|c|c|c|c|c|}
\hline \multirow{2}{*}{ Pond no. } & \multirow{2}{*}{$\begin{array}{l}\text { Length } \\
(\mathrm{m})\end{array}$} & \multirow{2}{*}{$\begin{array}{l}\text { Width } \\
\text { (m) }\end{array}$} & \multirow{2}{*}{$\begin{array}{l}\text { Water depth } \\
(\mathrm{m})\end{array}$} & \multirow{2}{*}{$\begin{array}{l}\text { Stocking density } \\
\text { (kg/ha) }\end{array}$} & \multicolumn{2}{|l|}{ Pesticides } & \multirow{2}{*}{ Cultured species } \\
\hline & & & & & Name & Dose & \\
\hline I & 46.0 & 44.0 & 0.75 & 3458 & $\begin{array}{l}\text { Sumithion, } \\
\text { Nogos and } \\
\text { Rejent }\end{array}$ & 0.13 & $\begin{array}{l}\text { Labeo rohita and } \\
\text { Cyprinus carpio }\end{array}$ \\
\hline
\end{tabular}

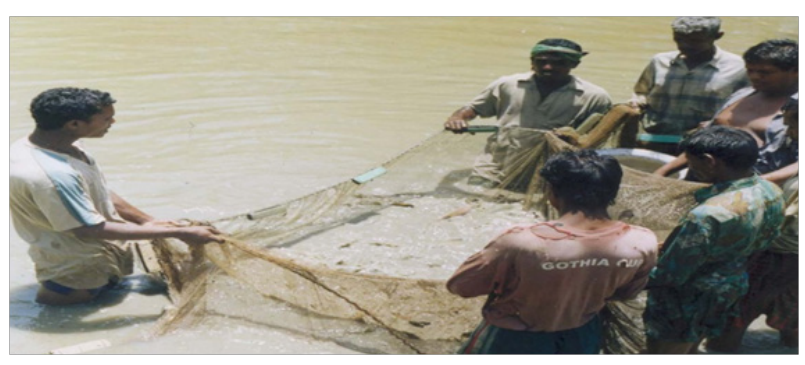

Figure I Sampling of carps by seine net to investigate Argulus infestation.

During the investigation, fishes were collected by seine net on weekly and monthly basis at a regular interval (Figure 1). A total of 1760 fishes were examined (including 451 that were infected) in which 540 individuals were Catla catla, 180 were Hypophthalmicthys molitrix, 180 were Aristichthys nobilis, 700 were Labeo rohita, 590 were Cirrhinus mrigala, and 110 were Cyprinus carpio. Prevalence and intensity were determined according to the formulas used by Margolis et al. ${ }^{14}$ as follows:

$$
\begin{gathered}
\text { Prevalence }(\%)=\frac{\text { Infected }}{\text { Examined }} \times 100 \\
\text { Intensity }=\frac{\text { No. of Argulus sp. }}{\text { Infected }}
\end{gathered}
$$

\section{Results and discussion}

\section{Status of Argulosis}

\section{Prevalence and intensity of infestation}

In the three hatchery ponds, $17.11-79.17 \%$ fishes were found to be infested by the Argulus sp. with the intensity of 10.91-41.34 parasites per fish (Table 4). Highest infestation was found in Ujirpur hatchery pond, where lower dose of pesticides was applied and the lowest rate was in Kashipur Farm ponds, might be due to regular use of higher dose of Sumithion. Table 5 shows that only L. rohita, C. mrigala and C. carpio were found to be infested during the entire study. Of them, overall highest prevalence $(65.71 \%)$ and intensity (25.86 per fish) was found in L. rohita followed by C. carpio $(60.00 \%$ and 12.00 per fish) and C. mrigala (38.61\% and 5.02 per fish). The farmers also reported that catla and other fishes like silver carp and bighead were also infected in the ponds but the rate was very low. Gopalakrishnan ${ }^{15}$ found L. rohita to be more susceptible to Argulosis than C. catla and C. mrigala. The rate of infestation was higher in Ujirpur and Gouranadi hatchery ponds as these were not well-managed and they used lower dose of pesticides. Overall, the rate of infestation (prevalence and intensity) was depended mainly on the use of pesticides dose and duration and management practices like maintenance of water quality, use of fertilizers and feed, water exchange etc. It was also difficult to assess the loss of fish production due to Argulosis as the farmers 
always use pesticides before reaching the situation of mortality However, it came out from the farmers that about $10-20 \%$ loss were triggered by the lower production of eggs, growth loss and even death caused due to over dose and heavily infected fishes becoming unfit for use.

\section{Fish sex-wise distribution of Argulus sp}

Table 6 shows that prevalence and intensity of Argulus sp. was always higher in the female carps than male and in all ponds, $L$. rohita had the highest rate of infestation, and the most infested carps were the females. Same results were also followed by $C$. carpio and $C$. mrigala.

Table 4 Total Prevalence and intensity of infestation by Argulus sp. in the host fishes of three hatcheries

\begin{tabular}{|c|c|c|c|c|c|}
\hline \multirow{2}{*}{$\begin{array}{l}\text { Name of } \\
\text { hatchery }\end{array}$} & \multicolumn{2}{|c|}{ No. of host fish } & \multirow{2}{*}{ No. of Argulus sp. } & \multirow{2}{*}{ Prevalence (\%) } & \multirow{2}{*}{$\begin{array}{l}\text { Intensity } \\
\text { (Mean) }\end{array}$} \\
\hline & examined & infected & & & \\
\hline Kashipur & 900 & 154 & 1680 & 17.11 & 10.91 \\
\hline Gouranadi & 540 & 202 & 2660 & 37.41 & 13.17 \\
\hline Ujirpur & 120 & 95 & 3927 & 79.17 & 41.34 \\
\hline Total & 1560 & 451 & 8267 & 28.91 & 18.33 \\
\hline
\end{tabular}

Table 5 Total prevalence and intensity of infestation by Argulus sp. only in the affected host fish species of three hatcheries

\begin{tabular}{|c|c|c|c|c|c|}
\hline \multirow{2}{*}{ Name of fish } & \multicolumn{2}{|c|}{ No. of host fish } & \multirow{2}{*}{ No. of Argulus sp. } & \multirow{2}{*}{ Prevalence (\%) } & \multirow{2}{*}{$\begin{array}{l}\text { Intensity } \\
\text { (Mean) }\end{array}$} \\
\hline & examined & infected & & & \\
\hline Labeo rohita & 420 & 276 & 7137 & 65.71 & 25.86 \\
\hline Cirrhinus mrigala & 360 & 139 & 698 & $38.6 \mathrm{I}$ & 5.02 \\
\hline Cyprinus carpio & 60 & 36 & 432 & 60.00 & 12.00 \\
\hline Total & 840 & 451 & 8267 & 53.69 & 18.33 \\
\hline
\end{tabular}

Table 6 Total sex wise prevalence and intensity of infestation of Argulus sp. only in the host fish species of Kashipur, Gouranadi and Ujirpur hatchery

\begin{tabular}{|c|c|c|c|c|c|c|}
\hline Name of fish & Sex & $\begin{array}{l}\text { exan } \\
\text { infec }\end{array}$ & fishes & No. of Argulus sp. & Prevalence (\%) & $\begin{array}{l}\text { Intensity } \\
\text { (Mean) }\end{array}$ \\
\hline \multirow{2}{*}{ Labeo rohita } & Male & 210 & 127 & 2882 & 60.48 & 22.69 \\
\hline & Female & 210 & 149 & 4255 & 70.95 & 28.56 \\
\hline \multirow{2}{*}{ Cirrhinus mrigala } & Male & 180 & 63 & 238 & 35.00 & 3.78 \\
\hline & Female & 180 & 76 & 460 & 42.22 & 6.05 \\
\hline \multirow{2}{*}{ Cyprinus carpio } & Male & 30 & 16 & 186 & 53.33 & 11.63 \\
\hline & Female & 30 & 20 & 246 & 66.67 & 12.30 \\
\hline
\end{tabular}

Table 7 Length-wise prevalence and intensity of infestation of Argulus sp. on Labeo rohita of three hatcheries

\begin{tabular}{|c|c|c|c|c|c|}
\hline \multirow{2}{*}{$\begin{array}{l}\text { Length groups } \\
(\mathrm{cm})\end{array}$} & \multicolumn{2}{|c|}{ No. of host fish } & \multirow{2}{*}{$\begin{array}{l}\text { No. of } \\
\text { Argulus }\end{array}$} & \multirow{2}{*}{$\begin{array}{l}\text { Prevalence } \\
(\%)\end{array}$} & \multirow{2}{*}{$\begin{array}{l}\text { Intensity } \\
\text { (Mean) }\end{array}$} \\
\hline & examined & infected & & & \\
\hline $30.0-44.9$ & 140 & 77 & 1295 & 55.00 & 16.81 \\
\hline $45.0-55.9$ & 140 & 93 & 2236 & 66.43 & 24.04 \\
\hline $60.0-74.9$ & 140 & 107 & 3647 & 76.43 & 34.08 \\
\hline
\end{tabular}


Table 8 Length-wise prevalence and intensity of infestation of Argulus sp. on Cirrhinus mrigala of three hatcheries

\begin{tabular}{llllll}
\hline \multirow{2}{*}{ Length groups (cm) } & \multicolumn{2}{l}{ No. of host fish } & No. of Argulus & Prevalence (\%) & Intensity (Mean) \\
\cline { 2 - 3 } & examined & infected & & & \\
\hline $30.0-44.9$ & 80 & 33 & 94 & 41.25 & 2.85 \\
$45.0-55.9$ & 80 & 46 & 175 & 57.50 & 3.80 \\
$60.0-74.9$ & 80 & 59 & 388 & 73.75 & 6.58 \\
\hline
\end{tabular}

Table 9 Length-wise prevalence and intensity of infestation of Argulus sp. on Cyprinus carpio of Ujirpur hatchery

\begin{tabular}{|c|c|c|c|c|c|}
\hline \multirow{2}{*}{ Length groups (cm) } & \multicolumn{2}{|c|}{ No. of host fish } & \multirow{2}{*}{ No. of Argulus } & \multirow{2}{*}{ Prevalence (\%) } & \multirow{2}{*}{$\begin{array}{l}\text { Intensity } \\
\text { (Mean) }\end{array}$} \\
\hline & examined & infected & & & \\
\hline $30.0-44.9$ & 20 & 9 & 52 & 45 & 5.78 \\
\hline $45.0-59.9$ & 20 & 12 & 135 & 60 & 11.25 \\
\hline $60.0-74.9$ & 20 & 15 & 245 & 75 & 16.33 \\
\hline
\end{tabular}

\section{Clinical signs of argulosis: oozing}

Infected fish shows physical injury and abnormal swimming. The Argulus first feed by inserting a pre-oral string which injects poisonous enzymes into the body and then suck out liquidized body fluid with their mouth tube. ${ }^{12}$ After suck out body fluid, it causes skin irritations and the fish starts sporadic swimming and rubbing the body on hard substrates, which is found near it. Localized swelling caused by constant piercing of the skin by the stylet (Figure 2) also results tissue damage and unraveled fins (Figure 3). Sometimes blood is discharged out from the fish body and bacteria like Aeromonas or Pseudomonas infects secondarily, causing red skin lesions (Figure 4). Secondary parasite and fungal infection may also take place. The combined attack on stressed and weakened fish results in high number of fatalities like anemia, and thin and darkened soft body (Figure 5). The fish become slim, weak and sluggish at later stage. Heavy infestation causes red and black spots all over the pelvic to the anal fin region, the fins look frayed and eyes appear sunken. The fish becomes morbid and unfit for breeding and thus table fish causing economic loss, which has been estimated to be $17-30 \%$ of total production. Similar result was also found by Ahmed. ${ }^{12}$

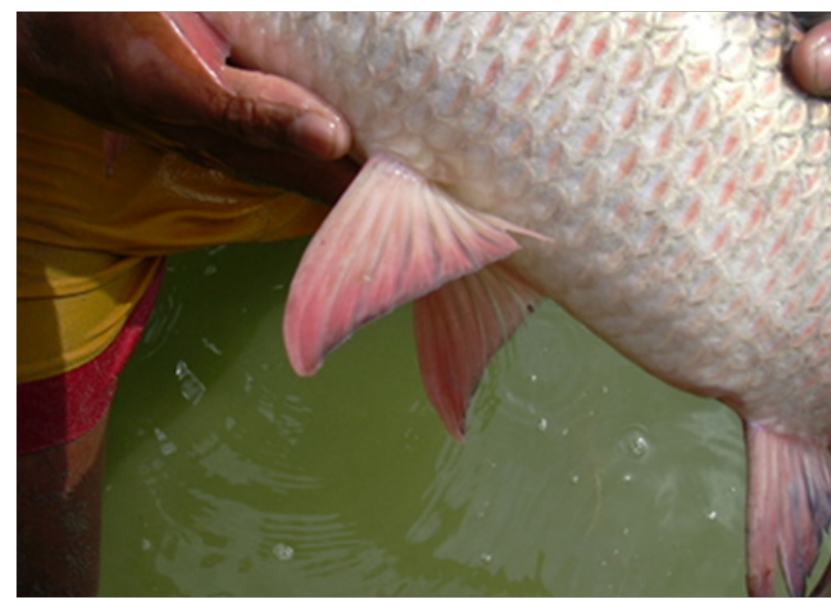

Figure 2 Argulus sp. infected pelvic fin and the symptom of secondary infection.

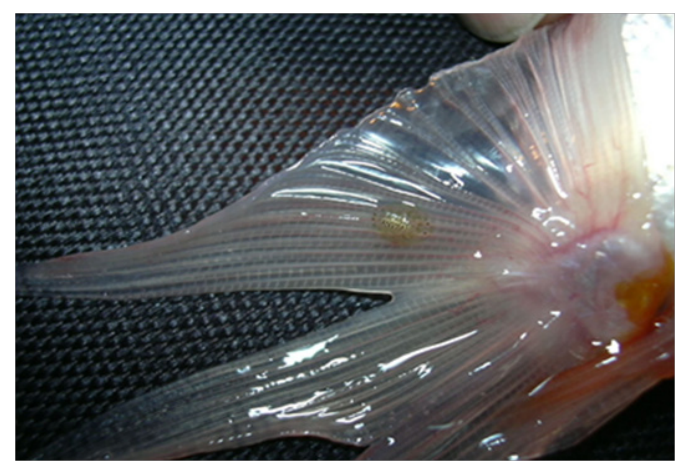

Figure 3 Argulus sp. infected Caudal fin.

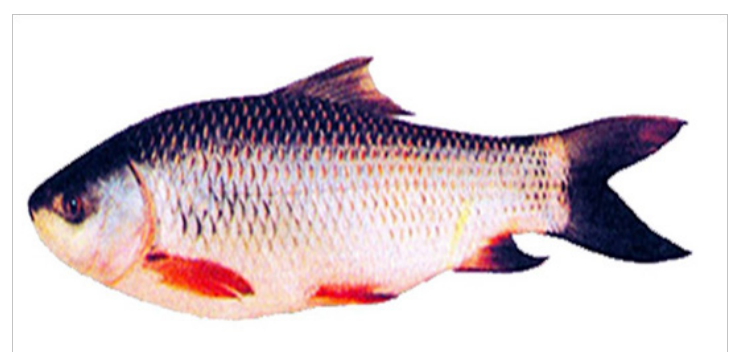

Figure 4 Argulus sp. infected gloomy Labeo rohita.

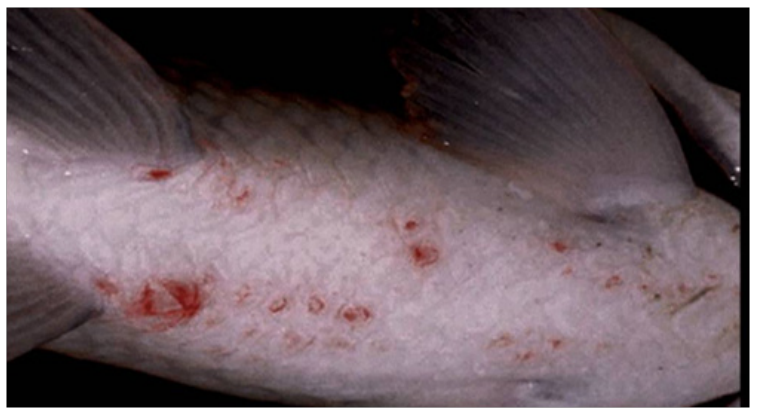

Figure 5 Argulus sp. infected lesions like anemia, thin and darkened soft body and fins. 
The Argulus infected host carps showed irritation. They penetrate some toxins through the sting, which cause strong hemorrhagic reaction. ${ }^{4}$ The host ceases feeding and loses weight. Same results were also observed by Das et al. ${ }^{17}$ Opaqueness of the skin and erosion of the fins were also observed by Stammer, ${ }^{9}$ who reported that host fish could generally carry many Argulus foliaceus with little sign of diseases. Argulus japonicus infected host showed occasional abnormal behavior of rubbing their bodies against the wall of the pond, which caused damage to the body surface leading to secondary infection. Mortalities of carps happened due to the heavy infection of Argulus sp. but nothing was mentioned about the treatment. ${ }^{5}$

The findings from the present study revealed that heavy infestation and intensity of Argulus could affect fish health as well as cause secondary infection, for which higher mortality (death) might be happened due to low growth, survival and production of carp fishes in captivity. It was also found that both the prevalence and intensity of infestation were higher in large-sized females than the smaller ones, which might be very hazardous for the development of commercial fish hatchery. It is therefore very urgently required to protect the severe infestation caused by the ecto-parasite (Argulus sp.), which might be very effective and easily adoptable with lower maintenance cost.

\section{Conflicts of interest}

The authors declared that there is no conflicts of interest.

\section{References}

1. Kollatsch D. Untersuchungen uber die biologie und okologie der Karpfenlaus (Argulus foliaceus L.). Zoologische Beitrage. 1959;5:1-36.

2. Hoffman GL, Meyer FP. Parasites of freshwater fishes. Neptune City, N.J: T.F.H. Publications; 1974. 224 p.

3. Tripathi YR. Common diseases of fish in India. Indian farming. 1969:8384.

4. Shimura S, Inoue K. Toxic effects of extract from the mouth- parts of Argulus coregoni Thorell (Crustacea: Branchiura). Bull Jap Soc Sci Fish. 1984;50(4):729.

5. Rahman AKA. A note on Argulus species which caused mortalities in carps in the experimental cistern of the Freshwater Research Station, Chadpur, East Pakistan. Pak J Sci Indust Res. 1968;2:115-118.
6. Ahmed ATA, Sanaullah M. Organal and percentage distribution of some metazoan parasites in Heteropneustes fossilis (Bloch) and Clarias batrachus. J Asiat Soc Bnagladesh. 1976;2(1):7-15.

7. Ahmed ATA, Chowdhury MM. Argulosis in brood carp ponds of Bangladesh. Presented at the $5^{\text {th }}$ Symposium on Diseases in Asian Aquaculture held at Gold Coast, Queensland, Australia. Fish Healtth Section of Asian Fisheries Society. 2002;18.

8. Stammer HJ. Observation on the habits and post-embryonic development of a parasitic branchiuran Argulus puthenveliensis Ramakrishna. J Mari Biol Assoc India. 1959;3:75-86.

9. Mikheev VN, Valtonen ET, Rintamäki-kinnunen P. Host searching in Argulus foliaceus L (Crustacea: Branchiura): the role of vision and selectivity. Parasitology. 1998;116:425-430.

10. Zhilyukas V, Rautskis SY. Parasitol. (Leningr). 1982;16:117-121.

11. Kimura S. Control of the fish lice, Argulus japonicus Thiele, with dipterex. Aquaculture. 1960;8:141-50.

12. Ahmed ATA. Environment friendly medical treatment of Argulosis in different brood stock ponds. DFID, SUFER project; 2004:30-36.

13. Baticados MCL, Paclibare JO. The use of chemotherapeutic agents in aquaculture in the Philippines. In: Shariff M, Subasinghe RP, Arthur JR, editors. Diseases in Asian Aquaculture I. Fish Health Section, Manila, Philippines: Asian Fisheries Society; 1992:531-546.

14. Margolis LGW, Esch JC, Holmes AM, et al. The use of ecological terms in Parasitology (Report of an Adhoc Committee of the American Society of Parasitologists). J Prasitol. 1982;68(1):131-133.

15. Gopalkrishnan V. Recent developments in the prevention and control of parasites of fishes cultured in Indian waters. Proc Zool Soc Calcutta. 1964; 17:95-100.

16. Shimura S. Seasonal occurrence, sex ratio and site preference of Argulus coregoni Thorell (Crustacea: Branchiura) parasitic on cultured freshwater salmonoid in Japan. Parasitology. 1983;86:537-552.

17. Das P, Kumar D, Ghosh Parasitology, et al. High yield of Indian major carps against encountered hazards in a demonstration pond. J Inland Fish Soc. 1980;12:70-78. 